\title{
"There was a Great Mortality in Rome, more Serious than is Recalled in the Time of any other Pontiff'. Plagues and Diseases in the Liber Pontificalis
}

The experience of illness leaves a profound mark on the history of individuals and societies ${ }^{2}$. Some scholars even stated that the plague that affected the Mediterranean world of the 6th-8th centuries was a breakthrough in marking the turning point between the end of antiquity and the beginning of the Middle Ages ${ }^{3}$.

Ecclesiastical authors who had left some historical writings from that period offer an opportunity to understand, although only in general terms, how plagues and diseases influenced local communities. Scholarly attention has already been given to the historical work of Gregory of Tours and Bede Venerabilis and the way they portrayed the plague in Gaul and Britain respectively ${ }^{4}$. The aim of this paper is to investigate how the papal biographers, who had composed the Liber Pontificalis, perceived plagues and diseases that threatened Italy, Rome, and their inhabitants. The article is going to demonstrate that the authors of the collection of papal biographies perceived the experience of illness in various contexts: as an event caused

1 Rev. Michal Ludewicz, ThD candidate at the Faculty of Teology, The John Paul II Catholic University of Lublin; e-mail: mludewicz@wp.pl; ORCID: 0000-0002-9473-7745.

2 For example the so-called Antonine plague that lasted from 165 to the mid-180s killed about 10 percent of the Roman Empire's population that by time of Marcus Aurelius (161-180) numbered 64 million people. See D.S. Potter, The Roman Empire at Bay AD 180-395, London - New York 2004, p. 17.

3 Cf. L.K. Little, Plague and The End of Antiquity. The Pandemic of 541-750, Cambridge 2007, p. XI.

4 For Gregory see: M. McCormick, Gregory of Tours on Sixth-Century Plague and other Epidemics, "Speculum” 96/1 (2021) p. 38-96. For Bede see: J.R. Maddicott, Plague in Seventh-Century England, "Past and Present" 156 (1997) p. 7-54. 
by natural factors, as a sign of divine disapproval, and as a metaphor of evil threatening the community. Illnesses were also considered as an important factor that affected the level of activity of the pontiffs and other people mentioned in the Liber Pontificalis.

First part of the article will provide a brief survey of the situation in Rome and Italy at the time of the composition of Liber Pontificalis. It will also contain some remarks about the Liber itself. The second will focus on plagues and diseases mentioned in the Liber Pontificalis, that have affected the entire community. The third part will contain information on diseases that have affected individuals.

\section{The situation in Italy in the eve of the composition of Liber Pontificalis}

Alan D. Lee stated that the population of the city of Rome during the fourth century numbered between half a million and a million ${ }^{5}$. Because of the damages caused by barbarian invasions and sacks during the fifth and sixth centuries the population of the Eternal City decreased considerably ${ }^{6}$. During the Gothic Wars (535-552) Rome was inhabited by about as few as 30000 people $^{7}$. It is in this context of tension caused by warfare ${ }^{8}$ and natural disasters that the Liber Pontificalis was being composed ${ }^{9}$.

5 Cf. A.D. Lee, From Rome to Byzantium AD 363 to 565: The Transformation of ancient Rome, Edinburgh 2013, p. 60.

6 For a survey of sieges of Rome in the 6th century see: C. Machado, Rome, sieges of, in: The Oxford Dictionary of Late Antiquity, v. 2, ed O. Nicholson, Oxford, 2018, p. 1308.

7 Cf. C. Hibbert, Rome. The Biography of a City, New York - London 1985, p. 74.

8 Regular war between Byzantines and Goths endured until 552/553 with minor skirmishes that lasted until 561, see P. Heather, The Restoration of Rome, Barbarian Popes and Imperial Pretenders, Oxford 2013, p. 166. In 568 Italy was invaded by the Lombards. See E. Fabbro, Warfare and the Making of Early Medieval Italy (568-652), New York 2020, p. 13-14.

9 For the Latin text I cite from the two-volumed Latin-Polish edition of Liber Pontificalis. For volume one: Liber Pontificalis I-XCVI (usque ad annum 772). Synodi et Collectiones Legum 9, ed. M. Ożóg - H. Pietras, ŹMT 74, Kraków 2014. For volume two: Liber Pontificalis XCVII-CXII (ann. 772-891), Synodi et Collectiones Legum 10, ed. M. Ożóg - H. Pietras, ŹMT 75, Kraków 2015. For the English translation I use that of Raymond Davis: The Book of Pontiffs (Liber Pontificalis). The Ancient Biographies 
The Liber Pontificalis is a collection of papal biographies from St. Peter up to Pope Stephen V $(+891)^{10}$. It was in all likelihood composed by clerks from the papal household ${ }^{11}$. The process of composition started in the early sixth century and lasted up to the ninth century ${ }^{12}$. The first stage of composition of the papal biographies can be dated soon after $536^{13}$. Rosamond McKitterick stated that despite the plurality of authorship over 300 years and the potential for many different perspectives, there is a notable thematic and narrative consistency in the text $t^{14}$. Walter Ullmann on the other side described the work as "a mixture of pure narrative and interpretation of events and movements" 15 . Although the Liber Pontificalis was primary concerned with the deeds of Roman bishops, it may be also considered as an important source of knowledge about Roman society as a whole in the period of transition between Late Antiquity and early Middle Ages (V-IX century) ${ }^{16}$.

The collection of papal biographies contains quite a lot remarks about disasters that threatened the Roman community ${ }^{17}$. The inhabitants

of First Ninety Roman Bishops do AD 715. Revised edition, translated with introduction and notes by Raymond Davis, Liverpool 2010 (thereafter cited as: Davis 2010); The Lives of the Eighth-Century Popes (Liber Pontificalis) Second Edition, Translated with an introduction and commentary by Raymond Davis, Liverpool 2007 (thereafter cited as: Davis 2007); The Lives of the Ninth-Century Popes (Liber Pontificalis), Translated with an introduction and commentary by Raymond Davis, Liverpool 1995 (thereafter cited as: Davis 1995).

10 Cf. C. Vogel, Liber Pontificalis, in: Encyclopedia of Ancient Christianity, v. 2, ed. A. Di Berardino, Downers Grove 2014, p. 564.

11 Cf. W. Ullmann, A Short History of the Papacy in the Middle Ages, LondonNew York 2005, p. 24.

12 Cf. R. McKitterick, Rome and the Invention of the Papacy. The Liber Pontificalis, Cambridge 2020, p. xi.

13 R. McKitterick, Rome and the Invention of the Papacy, p. 12.

14 Cf. R. McKitterick, Rome and the Invention of the Papacy, p. 71.

15 Cf. W. Ullmann, A Short History of the Papacy, p. 24.

16 The most recent introduction to Liber Pontificalis is: McKitterick, Rome and the Invention of the Papacy.

17 The list in text below derives (with changes) from: M. Ludewicz, "Bóg codziennie przez swoje stugi czyni znaki $i$ wielkie cuda". Cuda przejawem władzy Boga nad światem w świetle Liber Pontificalis, in: Kościót na drogach przeszłości, ed J. Walkusz M. Nabożny, Lublin 2020, p. 148. 
of Rome were endangered by fires ${ }^{18}$, floods ${ }^{19}$, earthquakes ${ }^{20}$ and famine ${ }^{21}$. They were also prone to diseases ${ }^{22}$. The authors of Liber Pontificalis made mentions about illnesses that affected the population of Rome as a whole as well as those that had effect only on individuals.

\section{Plagues mentioned in the Liber Pontificalis}

For the first time a plague was mentioned in the Liber Pontificalis while describing the pontificate of Boniface IV (608-615). The author of his biography recorded that there was famine accompanied by plagues (pestilentiae) and floods ${ }^{23}$. The author specified that these misfortunes were very serious (gravissime $)^{24}$. Unfortunately the biographer did not add any further details to that information; above all he did not specify what area has been affected by these disasters.

More information has been given in the second fragment of the Liber Pontificalis devoted to epidemic. The authors of the collection of papal biographies recorded that in 618, the last year of the pontificate of Deusdedit (615-618), disasters occurred among the people. First there was an earthquake and then a plague - an outbreak of scab disease ${ }^{25}$. The impact of

18 Cf. Liber Pontificalis, C. Paschalis (817-824) 7, ŹMT 75, p. 108, Davis 1995, p. 8; Liber Pontificalis CV. Leo IIII (847-855) 20, ŻMT 75, p. 20, Davis 1995, p. 119.

19 Cf. Liber Pontificalis LXXVIIII. Adeodatus (672-676) 5, ŹMT 74, p. 187, Davis 2010, p. 71. For a commentary to that episode see also: Stathakopoulos, Famine and Pestilence, p. 354-355; Liber Pontificalis XCVII. Hadrianus (772-795) 94, ŹMT 75, p. 45, Davis 2007, p. 167-168.

20 Cf. Liber Pontificalis XCVIII. Leo III (795-816) 31, ŹMT 75, p. 62, Davis 2007, p. 191-192.

21 Cf. Liber Pontificalis LXIV. Benedictus (575-579) 1, ŹMT 74, p. 167-168, Davis 2010, p. 59. For a commentary to that episode see also: Stathakopoulos, Famine and Pestilence, p. 316.

22 For a short list of plagues in Liber Pontificalis see: McKitterick, Rome and the Invention of Papacy, p. 50-51.

23 Cf. Liber Pontificalis LXVIIII. Bonifativs IIII (608-615) 1, ŹMT 74, p. 172, Davis 2010 p. 61. For a short commentary on these misfortunes see: Stathakopoulos, Famine and Pestilence, p. 341-342.

24 Cf. Liber Pontificalis LXVIIII. Bonifativs IIII (608-615) 1, ŹMT 74, p. 172, Davis 2010 p. 61. For a short commentary on these misfortunes see: Stathakopoulos, Famine and Pestilence, p. 341-342.

25 Cf. Liber Pontificalis LXX. Deusdedit (615-618) 3, ŹMT 74, p. 173, Davis 2010, p. 61: "Post hec secuta est clades in populo percussio scabearum, ut nullus poterat mor- 
the bug was so great that nobody was able to recognize their deceased relatives ${ }^{26}$. The plague was also recorded by Paul the Deacon ${ }^{27}$, a chronicler from the eighth century. He added, that it was the swelling and inflammation that occurred on the victims of the plague, that had made them unrecognizable ${ }^{28}$. Because of those symptoms Horace Mann had conjectured that the disease was perhaps Elephantiasis ${ }^{29}$. Scholars differ about a possible reaction of the pope to the misfortune of the people. On one side Jean Durliat had stated: "The earthquake and epidemic that shook Rome before his death did not seem to have particularly moved him" ${ }^{30}$, whereas H. Mann quotes a legend in which the pope meets a victim of the plague and, touched with compassion for his sufferings, kisses him and restores him to health ${ }^{31}$.

The third (combined perhaps with the fourth) plague mentioned in the Liber Pontificalis occurred during the pontificate of Pope Donus (676$678)^{32}$. It was preceded by $\operatorname{star}^{33}$ that had been visible in the east of the sky for three months. After the disappearance of the star very great mortality (maxima mors) appeared ${ }^{34}$. Dionysios Ch. Stathakopoulos had conjectured

tuum suum cognoscere". See also: J.N.D. Kelly, The Oxford Dictionary of Popes, Oxford - New York 1989, p. 69.

26 Cf. Liber Pontificalis LXX. Deusdedit (615-618) 3, ŹMT 74, p. 173, Davis 2010, p. 61. See also: G. Arnaldi, Deusdedit, in: Enciclopedia dei papi, v. 1: Pietro, santo Anastasio bibliotecario, antipapa, ed G. Barone et al., Roma 2000, p. 583.

27 Paulus Diaconus, Historia Langobardorum, ed. L. Bethmann - G. Waitz, Monumenta Germaniae Historica, Scriptores Rervm Langobardicarvm et Italicarvm saec. VI-IX, Hannoverae 1878, p. 12-187. For the English translation: History of the Langobards by Paul the Deacon, tr. W.D. Foulke, Philadelphia 1907 (thereafter cited as: Foulke).

28 Cf. Paulus Diaconus, Historia Langobardorum II 4, p. 135, Foulke, p. 200. For Paul's mistaken chronology see Foulke, p. 200, n. 3.

29 H. Mann, The Lives of the Popes in The Early Middle Ages, v. 1: The Popes under the Lombard Rule, St. Gregory I. (The Great) to Leo III 590-795, Part I: 590-657, London 1914 , p. 282. For a survey of ancient opinions about skin diseases see: N.G. Stavrianeas - E. Toumbis Ioannou, Constantine the Great and leprosy: fact or fiction?, "Clinics in Dermatology" 27 (2009) p. 139-141.

30 J. Durliat, Adeodatus I, in: The Papacy, An Encyclopedia, v. 1, ed P. Levillain, New York - London 2002, p. 5.

31 Cf. H. Mann, The Lives of the Popes in The Early Middle Ages, v. 1, p. 1, London 1914, p. 282. For this episode see also: C.E. Sheedy, Deusdedit, Pope, St., in: New Catholic Encyclopedia, v. 4, New York 1967, p. 822.

32 Cf. Liber Pontificalis LXXX. Donus (676-678) 3, ŹMT 74, p. 188, Davis 2010, p. 72.

33 Cf. Stathakopoulos, Famine and Pestilence, p. 358 states that it was a comet.

34 Cf. Liber Pontificalis LXXX. Donus (676-678) 3, ŹMT 74, p. 188, Davis 2010, p. 72. 
that this epidemic may have been connected with another - one from 680, narrated in the life of Pope Agatho (678-681) 35 about which much more is known. There is indeed some similarity: whereas the former plague was preceded by a star, the latter followed an eclipse of the moon ${ }^{36}$. The chronicler had underlined the gravity of the situation caused by the plague in 680 . The epidemic was labeled great (maior) and grave (gravissima), without a parallel in the past ${ }^{37}$. The author of the papal biography had left some details about human behavior toward the disease and the progress of the illness: "[...] so that parents and their children, brothers and their sisters, were taken in pairs on biers to their graves. Afterwards it kept causing devastation out in the suburbs and walled towns all around" 38 . Paul the Deacon had recorded that plague as well. His description appears even more expressive:

[...] there followed a very severe pestilence for three months, that is, in July, August and September, and so great was the multitude of those dying that even parents with their children and brothers with their sisters were placed on biers two by two and conducted to their tombs at the city of Rome ${ }^{39}$.

H. Mann had conjectured that perhaps Pope Agatho's death was (directly or indirectly) caused by the pestilence ${ }^{40}$.

Apart from presenting plagues as pure natural disasters, authors of the Liber Pontificalis also perceived epidemic as an instrument of divine wrath. The author of the life of Pope Hadrian narrated about the pope's dealings with the Langobard ruler Desiderius. After being threatened by the king who had marched on Rome in 772, Hadrian appealed to Charlemagne for support ${ }^{41}$. As an effect of the papal request, the Frankish army entered Italy

35 Cf. Stathakopoulos, Famine and Pestilence, p. 358.

36 Cf. Liber Pontificalis LXXXI. Agatho (678-681) 4, ŹMT 74, p. 189, Davis 2010, p. 72: "Huius temporibus indictione VIII luna eclypsin pertulit mense Iunio die XVIII. Similiter et mortalitas maior atque gravissima sub secuta est mense supra scripto et mense Iulio, Augusto et Septembri in urbe Roma".

37 Cf. Liber Pontificalis LXXXI. Agatho (678-681) 4, ŹMT 74, p. 189, Davis 2010, p. 72: "[...] qualis nec temporibus aliorum pontificum esse memoratur".

38 Liber Pontificalis LXXXI. Agatho (678-681) 4, ŹMT 74, p. 189, Davis 2010, p. 72.

39 Paulus Diaconus, Historia Langobardorum VI 5, p. 166, Foulke, p. 255. Cf. Stathakopoulos, Famine and Pestilence, p. 359.

40 Cf. Mann, The Lives of the Popes in The Early Middle Ages, v. 1, p. 2, p. 47.

${ }^{41}$ For a summary of the relations between Desiderius, Hadrian and Charlemagne see: N. Christie, The Lombards, The ancient Longobards, Oxford 1998, p. 105-106. 
and besieged Desiderius in his capital - Pavia. In the Liber Pontificalis there can be found a relation from the last days of the siege that lasted until June $774^{42}$ :

When God's wrath raged furiously against all the Lombards inside that city and many were lost by disease and annihilation (mortalitatis clade), so it was God's will that His Excellency the king of the Franks captured the city along with Desiderius king of the Lombards and all his companions and reduced the entire Lombard kingdom into his own power ${ }^{43}$.

In the author's opinion it was God himself who was against the Lombards. The strike of the epidemic was a visual sign his displeasure toward them. It was an expression of God's will to surrender the city to the hands of Charlemagne and to subordinate Desiderius to him.

Apart from depicting pestilence as a physical misfortune, the authors of the Liber Pontificalis had also used that term in a moral sense - to describe their disapproval of marital misconduct of a certain ruler. During the pontificate of Pope Nicholas I (858-867) the papacy became involved in the case of King Lothair II's divorce ${ }^{44}$. The king had repudiated his wife Theudberga and wanted to marry his concubine Waldrada. The author of the pope's vita reported:

When the supreme pontiff was long contemplating within himself how he could expel this evil from God's church in case that king might pollute others with the plague of this sickness (huius morbi peste), he began to be troubled. Grieving in his inmost heart he mourned mightily over these errors; $[\ldots]^{45}$.

42 Cf. T.X. Noble, The Republic of St. Peter, The Birth of The Papal State (680-825), Philadelphia 1991, p. 131-132.

43 Liber Pontificalis XCVII. Hadrianus (772-795) 44, ŹMT 75, p. 18, Davis 2007, p. 139. For the details of the campaign see: B. Bachrach, Charlemagne's Early Campaigns (768-777), A Diplomatic and Military Analysis, Leiden 2013, p. 321-383.

44 As Stuart Airlie had stated: „The divorce case of Lothar II was a key political issue in the Carolingian world in the 850s and 860s. Four kings, two popes and a host of bishops and secular aristocrats were caught up in its ramifications" (S. Airlie, Private Bodies and the Body Politic in the Divorce Case of Lothar II, "Past and Present" 161 (1998) p. 4). For a brief summary of Nicholas' involvement in the case see: J. Roy, Saint Nicholas I, London 1901, p. 80-84.

45 Liber Pontificalis CVII. Nicolaus (858-867) 45, ŹMT 75, p. 232, Davis 1995, p. 226. 
During his lifetime, the pope had firmly opposed the king's actions and defended the indissolubility of marriage.

When dealing with the plague the authors of the Liber Pontificalis used several terms like: pestilentia ${ }^{46}$, clades $^{47}$, mors $^{48}$. These were often augmented by adjectives like gravissima ${ }^{49}$, maxima $^{50}$, maior $^{51}$. In most of the fragments the epidemic appeared combined with other calamities like earthquakes $^{52}$, floods ${ }^{53}$, famine ${ }^{54}$. Usually it was presented as caused by natural factors, but there was also a fragment attributing the eruption of the plague to divine disfavour toward the Lombards ${ }^{55}$. In the case of the attempted divorce of King Lothar II the terms connected with plague and sickness were used to describe the pope's disfavour towards the ruler's moral misbehaviour.

\section{Diseases that affected individuals mentioned in the Liber Pontificalis}

As bishops of Rome were the main characters described in the Liber Pontificalis, it was the context of their state of health that diseases were mentioned by the authors of the collection. The level of activities of each pope was often associated with his wellbeing. As Pierre-Andre Sigal has

46 Cf Liber Pontificalis LXVIIII. Bonifativs IIII (608-615) 1, ŹMT 74, p. 172, Davis 2010 p. 61.

${ }^{47}$ Cf. Liber Pontificalis LXX. Deusdedit (615-618) 3, ŹMT 74, p. 173, Davis 2010, p. 61.

48 Cf. Liber Pontificalis LXXX. Donus (676-678) 3, ŹMT 74, p. 188, Davis 2010, p. 72.

49 Cf. Liber Pontificalis LXXXI. Agatho (678-681) 4, ŹMT 74, p. 189, Davis 2010, p. 72.

50 Cf. Liber Pontificalis LXXX. Donus (676-678) 3, ŹMT 74, p. 188, Davis 2010, p. 72 .

51 Cf. Liber Pontificalis LXXXI. Agatho (678-681) 4, ŹMT 74, p. 189, Davis 2010, p. 72 .

52 Cf. Liber Pontificalis LXX. Deusdedit (615-618) 3, ŹMT 74, p. 173, Davis 2010, p. 61.

53 Cf. Liber Pontificalis LXVIIII. Bonifativs IIII (608-615) 1, ŹMT 74, p. 172, Davis 2010 p. 61.

${ }^{54}$ Cf. Liber Pontificalis LXVIIII. Bonifativs IIII (608-615) 1, ŹMT 74, p. 172, Davis 2010 p. 61.

55 Cf. Liber Pontificalis XCVII. Hadrianus (772-795) 44, ŹMT 74, p. 44, Davis 2007, p. 139. 
observed, many of the popes especially in the 7th century were elected in an advanced age and the role that they were able to play was accordingly reduced ${ }^{56}$.

First among the popes about whom something more is known in the case of health was Vigilius (537-555). Involved in the Christological controversies of his age, he was summoned by Justinian and Theodora to Constantinople and spent there considerable time ${ }^{57}$. In 555 while on his journey back to Rome, he died in Syracuse. The cause of his death was the gallstone disease. Narrating Vigilius' sail the author of his biography reported briefly: "They came to the city of Syracuse in Sicily. In agony from his affliction with gallstones (adflictus calculi dolorem), Vigilius died" 58 . The author of the pope's vita did not include many details describing Vigilius' condition. He only had underlined the intensiveness of the pope's sufferings. Claire Sotinel has stated that the disease he had been suffering from must have lasted for a considerable period of time ${ }^{59}$.

Next disease mentioned in the Liber Pontificalis was gout. There were at least two popes affected by that illness. First of them was Sisinnius (708). The author of his vita reported some miserable details revealing how did the disease handicapped the pope's abilities: "This man was so crippled by

56 Cf. P.-A. Sigal, Sickness of the Pope, Middle Ages, in: The Papacy, An Encyclopedia, v. 3, ed. P. Levillain, New York - London 2002, p. 1416. Perhaps Sigal's observations may be applicable to the sixth century as well. From that period we hear about Pope John I (523-526) who weak from illness (egrotus infirmitate), travelled to Constantinople on King's Theoderic demand. Cf. Liber Pontificalis LV. Iohannes I (523-526), 2, ŹMT 74, p. 148, Davis 2010, p. 48. Pope Agapitus (535-536) died in Constantinople because of an illness (egritudine commotus defunctus est). Cf. Liber Pontificalis LVIIII. Agapitus (535-536), 6, ŹMT 74 p. 156, Davis 2010, p. 52. As for the seventh century, in the life of Pope John V (685-686) it was mentioned that he was weakened by long-term illness (diutina infirmitate detentus), so that he could hardly even complete the ordinations of sacerdotes. Cf. Liber Pontificalis LXXXIIII. Iohannes $V$ (685-686), 5, ŹMT 74, p. 197, Davis 2010, p. 79. The same infirmity was ascribed to Pope Conon (686-687). Cf. Liber Pontificalis LXXXV. Conon (686-687), 5, ŹMT 74, p. 198 , Davis 2010, p. 80 .

57 He was forced to leave Rome for Constantinople in November 545 and detained in the emperor's capital until 555. For details see Kelly, The Oxford Dictionary of Popes, p. 60-62, C. Sotinel, Vigilius, in: The Papacy, An Encyclopedia, v. 3, ed. P. Levillain, New York - London 2002, p. 1616-1618.

\footnotetext{
58 Liber Pontificalis LXI. Vigilius (537-555) 9, ŹMT 74, p. 9, Davis 2010, p. 57.

59 Cf. Sotinel, Vigilius, p. 1618.
} 
a gouty humour that he could not take his food with his own hands" ${ }^{60}$. It is worth mentioning that in contrast to his limited physical capacities was the pope's strong will. His biographer reported that the pontifex had a resolute mind and was concerned for the inhabitants of Rome ${ }^{61}$. Nevertheless he was unable to achieve considerable effects because of his sudden death just 20 days after his papal consecration ${ }^{62}$. The next pope about whom it is known that he had suffered from gout was Sergius II (844-847). In a highly critical remark the author of his vita had written:

Now as this pontiff's limbs were weak from a gouty humour, he had lost the power to walk on his feet and had almost lost the use of his hands; but he was rancorous, uncontrolled in speech and given to wrangling, unstable in deed and word, treating everything lightly. That was why the leaders of the Romans set him as nought ${ }^{63}$.

The pope's immobility had profound political consequences because he had relinquished his power to his brother Benedict. According to Liber Pontificalis that man acted like an usurper and made much harm to the Roman people ${ }^{64}$.

Another illness described in the collection of papal biographies was apoplexy. Although not named explicitly, it could be interpreted from the symptoms that had appeared before the death of Pope Stephen just after a four-day pontificate in March 752. In the vita of his immediate successor - Stephen II (752-757) can be read:

Now when lord pope Zacharias of blessed memory died, the whole people elected themselves a priest named Stephen to the order of the pontificate and placed him in the Lateran patriarchate, where he lasted two days: on the third day when he had risen from his sleep and was at his seat managing his house-

60 Liber Pontificalis LXXXVIIII. Sisinnius (708) 1, ŹMT 74, p. 207, Davis 2010, p. 87: "Qui vir podagrico humore ita tenebatur constrictus, ut sibi cibum propriis manibus exhibere non valeret".

${ }^{61}$ Cf. Liber Pontificalis LXXXVIIII. Sisinnius (708) 1, ŹMT 74, p. 207, Davis 2010, p. 87.

${ }_{62}$ Cf. Kelly, The Oxford Dictionary of Popes, p. 85.

63 Liber Pontificalis CIIII. Sergius II (844-847) 40, ŹMT 74, p. 159, Davis 1995, p. 92.

64 Cf. Liber Pontificalis CIIII. Sergius II (844-847) 40, ŹMT 75, p. 159-160, Davis 1995, p. 92: "Erat denique illius pontificis fratrer quidam, nomine Benedictus, brutus et stolidus valde, qui propter imbecillitatem illius pontificis curam ecclesiasticam et publicam immerito usurpaverat". 
hold affairs, suddenly as he sat there he was deprived of his senses and struck dumb. Next day he died ${ }^{65}$.

The sudden death of Stephen, even before he was consecrated had caused some confusion in numbering the following popes bearing the same name $^{66}$.

Beside the popes, the Liber Pontifcalis mentions others individuals who had suffered from diseases. For the first time a layperson affected by an illness was recorded in the life of Silvester. It was Constantine the Great ${ }^{67}$. According to a legend recalled in the pope's vita, the emperor had suffered from leprosy ${ }^{68}$. Narrating the pope's dealings with Constantine the author of his biography stated:

He was in exile on Mount Syraptim "troubled by Constantine's persecution"; afterwards he returned in glory and baptized the emperor Constantine, whom the Lord cured from leprosy "by baptism", and from whose persecution he is known to have previously fled into exile ${ }^{69}$.

The author of Silvester's vita had referred to a legend that in its most complete form was included in a text called Actus Silvestrii ${ }^{70}$. There it can be read that Constantine, a pagan and persecutor of Christians had fallen ill with leprosy ${ }^{71}$. Unwilling to follow an advice of the pagan priests and bathe

${ }_{65}$ Liber Pontificalis XCIV. Stephanus II (752-757) 2, ŹMT 74, p. 248, Davis 2007, p. 52.

66 For details see the unsubscribed entry: Stephen (Popes), in: The Papacy, An Encyclopedia, v. 3, ed. P. Levillain, New York - London 2002, p. 1454-1455.

${ }_{67}$ R. McKitterick stated that the story of Silvester's dealing with Constantine depicted in the Liber Pontificalis is a combination of historical reconstruction, deliberate selection, and political use of fiction. Cf. McKitterick, Rome and the Invention of the Papacy, p. 99.

${ }_{68}$ Cf. Liber Pontificalis XXXIIII. Silvester (314-335) 2, ŹMT 74, p. 64, Davis 2010 , p. 14. For leprosy as a possible metaphor for paganism see: Cf. McKitterick, Rome and the Invention of the Papacy, p. 98, n. 5.

${ }^{69}$ Liber Pontificalis XXXIIII. Silvester (314-335) 2, ŹMT 74, p. 64, Davis 2010, p. 14.

70 Referring to the content of the document I quote the conclusions of Paolo Liverani from: P. Liverani, Saint Peter's, Leo the Great, and the Leprosy of Constantine, "Papers of the British School at Rome" 76 (2008) p. 166. I already have discussed this episode in: Ludewicz, "Bóg codziennie przez swoje stugi czyni znaki i wielkie cuda", p. 150.

71 According to Nikolaos G. Stavrianeas the author of the legend while referring to "leprosy" had in fact in mind some kind of dermatological disease affecting only the surface 
in the blood of children, he had received advice from the apostles Peter and Paul to seek for pope Silvester. After returning from his retreat on Mount Soracte, where he has been hiding because of Constantine's persecutions, the pope had advised the emperor to receive baptism. The sacrament had healed the emperor, who from thereafter had changed his attitude toward Christians and became a benefactor of the Church ${ }^{72}$. According to the account in the Liber Pontificalis it was the Lord himself who had healed the emperor through the ministry of Silvester. This scene, depicting the pope granting favor to the emperor, had profound implications for the later relationship between the imperial office and the papacy.

Thanks to divine intervention leprosy didn't occur a terminal illness for Constantine. But the Liber Pontificalis also depicted diseases that had lead people to death. In 753 Pope Stephen II (752-757) who had been seeking aid against the Lombards was on route to Francia, to visit King Pepin $^{73}$. In the pope's retinue there was Ambrose primicerius notariorum. It was perhaps during the last days of 753 when Stephen's suite, after crossing the Great St. Bernard, had reached the monastery of St. Maurice at Agaune ${ }^{74}$. The author of the pope's vita had remarked shortly: "[...] it was there that the primicerius Ambrose caught fever (febre correptus) and died"75. It may be added that because of the inconvenience of travel the health of the pope himself was in danger and when he finally had reached the monastery of St. Denis he had felt ill and many from his companions had expected him to die. Nevertheless due to the Lord's assistance Stephen had recovered ${ }^{76}$.

Another episode where a disease that led to death has been described was recorded in the biography of Pope Stephen III (768-772). After the

of the skin instead of "real" leprosy that harms skin tissue along its entire depth (Stavrianeas - Toumbis Ioannou, Constantine the Great and leprosy: fact or fiction?, p. 140).

72 For further details about the legend, see Stavrianeas - Toumbis Ioannou, Constantine the Great and leprosy: fact or fiction?, p. 139; K. Sessa, Exceptionality and Invention: Silvester and the Late Antique 'Papacy'at Rome, "Studia Patristica" 46 (2010) p. 87-89.

73 For the political circumstances of the visit, see Noble, The Republic of St. Peter, p. 74-81.

74 Cf. Noble, The Republic of St. Peter, p. 80.

75 Liber Pontificalis XCIV. Stephanus II (752-757) 24, ŹMT 74, p. 255, Davis 2007, p. 61.

76 Cf. Liber Pontificalis XCIV. Stephanus II (752-757) 28, ŹMT 74, p. 257, Davis 2007, p. 63. For the motif of divine assistance during the pope's journey from Rome to Francia, see also Ludewicz, "Bóg codziennie przez swoje stugi czyni znaki i wielkie cuda", p. 155-156. 
death of Pope Paul in 767 there occurred some controversies about his successor. The secular aristocracy of Rome had seized the opportunity and imposed the election of a certain Constantine, a layman. He was then given all the clerical orders and ordained bishop by George, bishop of Palestrina ${ }^{77}$. Not long afterwards the bishop fell ill and died. The Liber Pontificalis had recorded the deterioration of his health:

But Bishop George of Palestrina who had consecrated Constantine deacon and pontiff was a few days after that consecration stricken with a serious and noxious illness and rendered immobile. He never again celebrated the ceremonies of mass: his right hand withered and shrivelled - he could not even reach his mouth with it. Thus he wasted away and became weaker, and his life came to an end $^{78}$.

The symptoms described by the author of the papal vita reveal that the bishop had presumably suffered a stroke that had resulted in paralysis and ultimately death. The author had stressed the proximity between the bishop's illegal action (the ordination of Constantine) and his miserable fate (note the details concerning his disability to eat and to celebrate the mass). Perhaps, although this was not stated directly, the rapid progress of the illness has been perceived as a sign of divine punishment for the bishop's illicit action.

In the Liber Pontificalis there can also be found a reference to an unnamed disease that had resulted with the death of Olympius, a Byzantine exarch in Italy. He had been appointed in 649 and given orders to surrender Pope Martin I (649-654) to the line of the religious policy of the emperor Constans $\mathrm{II}^{79}$. Unable to fulfill the task, Olympius had raised rebellion and marched to Sicily, where he had met his end. The author of Pope Martin's vita noted:

So when Olympius saw that God's hand was shielding holy Pope Martin, he was forced to reconcile himself to the pontiff and disclose all his orders to that

77 For the controversies surrounding Constantine's election, see Kelly, The Oxford Dictionary of Popes, p. 93-94.

78 Liber Pontificalis XCVI. Stephanus III (768-772) 6, ŹMT 74, p. 272, Davis 2007, p. 89.

79 For the religious conflict between the emperor and the pope and the role Olympius had played in it see: E. Rubery, Conflict or Collusion? Pope Martin (649-654/5) and the Exarch Olympius in Rome after the Lateran Synod of 649, "Studia Patristica" 52 (2012) p. 339-367 (especially p. 341-352). 
holy man. Now that he had made peace with God's holy church he mustered the army and set out for Sicily against the Saracen ${ }^{80}$ people who were living there. The result of sin was that the destruction befalling the Roman army was all the greater. After this the exarch died of disease (morbo interiit) ${ }^{81}$.

The author marked a connection between some religious misbehavior ( $\sin )$ and the army's fatal collapse. Perhaps referring to the death of Olympius from an unnamed illness he had somehow associated it with divine will as well.

The majority of individual cases where diseases were mentioned in the Liber Pontificalis referred to the health of the popes. Being elected in an advanced age they were prone to diseases. In some cases an illness was an ultimate reason of the pope's death (like Vigilius' gallstones), in other the disability had considerably limited the activity of popes (Sisinnius' and Sergius' II gout). Besides the popes the Liber Pontificalis had mentioned other individuals affected by illnesses. Some of the accounts were legendary (like Constantine's leprosy). Some were seen a consequence of one's misbehavior (the cases of George of Palestrina and perhaps exarch Olympius). Finally, some of them were perceived as a natural aftermath of the harshness of travel conditions (the case of the primicerius Ambrose).

In every epoch an encounter with a plague or an illness had considerable consequences for societies and individuals. It revealed humans fragility in the collision with the unknown forces of nature. For the inhabitants of Rome in the epoch of shift between Antiquity and the Middle Ages plagues were one of many disadvantages they had to struggle with. Pestilences were accompanied by famine, floods, earthquakes. In most cases plagues were perceived as natural disasters, although there were episodes where a pestilence was considered as a sign of divine wrath. An image of a plague was also used to describe the danger of moral evil infecting the manners of Christians. In addition to plagues the authors of the Liber Pontificalis had also described diseases, mostly those affecting the popes. An illness may have had a deep impact on the level of activity of certain bishops of Rome. In the collection of papal biographies there were also descriptions of diseases that had affected other people: an emperor, bishop, soldier, clerk. Even if not all of the illnesses appeared terminal, each of them had greatly affected one's life.

80 For the puzzled question of "Saracens" in Sicily see: D. Woods, Olympius and the "Saracens" of Sicily, "Byzantine and Modern Greek Studies" 27 (2003) p. 262-265.

81 Liber Pontificalis LXXVI. Martinus I (649-655) 7, ŹMT 74, p. 183, Davis 2010, p. 68. 


\section{"There was a Great Mortality in Rome, more Serious than is Recalled in the Time of any other Pontiff". Plagues and Diseases in the Liber Pontificalis}

(summary)

The aim of this article was to describe how were plagues and illnesses perceived by the authors of the Liber Pontificalis. In the first part circumstances in which the first draft of the Liber Pontificalis was composed were analysed. Attention was given particularly to disadvantages that affected the population of Italy in the $6^{\text {th }}$ century. The second part was devoted to plagues recorded in the Liber Pontificalis. When dealing with the plague the authors of the Liber Pontificalis used several terms like: pestilentia, clades, mors. In most cases plagues were presented as being caused by natural factors. But a statement attibuting the eruption of the pestilence to divine disfavour can also be found. The third part was concerned with diseases that had affected individuals. The majority of cases where diseases were mentioned in the Liber Pontificalis referred to the health of the popes. In the collection of papal biographies there were also descriptions of diseases that had affected other people: an emperor, bishop, soldier, clerk. Even if not all of the illnesses appeared terminal, each of them had greatly affected one's life.

Keywords: Liber Pontificalis; plague; pestilence; illness; Rome; papacy

\section{„Wielka i bardzo ciężka zaraza nastąpiła w Rzymie, jakiej nie pamiętano za czasów innych pontyfików". Zarazy i choroby według Liber Pontificalis}

(streszczenie)

Celem artykułu jest ukazanie, w jaki sposób autorzy Liber Pontificalis postrzegali doświadczenie zarazy i choroby. W pierwszej części tekstu scharakteryzowano okoliczności powstania zbioru papieskich biografii. Szczególny nacisk położony został na zagrożenia, z jakimi zmagała się ludność Italii w VI wieku. Druga część pracy poświęcona została wybuchom zarazy przedstawionym w Liber Pontificalis. Opisując rzeczywistość zarazy, autorzy posługiwali się terminami pestilentia, clades, mors. Najczęściej zarazy przedstawiano jako wydarzenia spowodowane przyczynami naturalnymi. Jednakże odnaleźć można również fragment przypisujący wybuch zarazy gniewowi Bożemu. Trzecia część pracy dotyczy chorób, które dotykały jednostek. Autorzy Liber Pontificalis, co zrozumiałe, byli najbardziej zainteresowani informacjami na temat zdrowia papieży. Przekazali jednakże również informacje o chorobach, które dotknęły cesarza, biskupa, żołnierza czy urzędnika. Choć tylko niektóre ze schorzeń okazały się śmiertelne, z lektury Liber Pontificalis można wyciągnąć wniosek, że każda z dolegliwości wywierała konkretny wpływ na życie doświadczanej przez nią jednostki.

Słowa kluczowe: Liber Pontificalis; zaraza; plaga; choroba; Rzym; papiestwo 


\section{Bibliography}

\section{Primary sources}

Liber Pontificalis I-XCVI (usque ad annum 772), ed. M. Ożóg - H. Pietras, Synodi et Collectiones Legum 9, ŹMT 74, Kraków 2014; Liber Pontificalis XCVII-CXII (ann. 772-891), ed. M. Ożóg - H. Pietras, Synodi et Collectiones Legum 10, ŹMT 75, Kraków 2015, tr. R. Davis, The Book of Pontiffs (Liber Pontificalis). The Ancient Biographies of First Ninety Roman Bishops to AD 715, Liverpool 2010; The Lives of the Eighth-Century Popes (Liber Pontificalis), Liverpool 2007; The Lives of the Ninth-Century Popes (Liber Pontificalis), Liverpool 1995.

Paulus Diaconus, Historia Langobardorum, ed. L. Bethmann - G. Waitz, Monumenta Germaniae Historica, Scriptores Rervm Langobardicarvm et Italicarvm saec. VIIX, Hannoverae 1878, p. 12-187, tr. W.D. Foulke, History of the Langobards by Paul the Deacon, Philadelphia 1907.

\section{Secondary sources}

Arnaldi G., Deusdedit, in: Enciclopedia dei papi, v. 1: Pietro, santo - Anastasio bibliotecario, antipapa, ed. G. Barone et al., Roma 2000, p. 582-583.

Airlie S., Private Bodies and the Body Politic in the Divorce Case of Lothar II, "Past and Present" 161 (1998) p. 3-38.

Bachrach B., Charlemagne's Early Campaigns (768-777), A Diplomatic and Military Analysis, Leiden 2013.

Christie N., The Lombards, The ancient Longobards, Oxford 1998.

Durliat J., Adeodatus I., in: The Papacy, An Encyclopedia, v. 1, ed. P. Levillain, New York - London 2002, p. 5-6.

Fabbro E., Warfare and the making of Early Medieval Italy (568-652), New York 2020.

Heather P., The Restoration of Rome, Barbarian Popes and Imperial Pretenders, Oxford 2013.

Hibbert C., Rome. The Biography of a City, New York - London 1985.

Kelly J.N.D., The Oxford Dictionary of Popes, Oxford - New York 1989.

Lee A.D., From Rome to Byzantium AD 363 to 565: The Transformation of ancient Rome, Edinburgh 2013.

Liverani P., Saint Peter's, Leo the Great, and the Leprosy of Constantine, "Papers of the British School at Rome" 76 (2008) p. 155-172.

Little L.K., Plague and The End of Antiquity. The Pandemic of 541-750, Cambridge 2007. Ludewicz M., „Bóg codziennie przez swoje sługi czyni znaki i wielkie cuda”. Cuda przejawem władzy Boga nad światem w świetle Liber Pontificalis, in: Kościót na drogach przeszłości, ed. J. Walkusz - M. Nabożny, Lublin 2020, p. 145-160.

Machado C., Rome, sieges of, in: The Oxford Dictionary of Late Antiquity, ed. O. Nicholson, v. 2, Oxford 2018, p. 1308. 
Mann H., The Lives of the Popes in The early Middle Ages, v. 1: The Popes under the Lombard Rule, St. Gregory I. (The Great) to Leo III 590-795, p. 1: 590-657, London 1914.

Mann H., The Lives of the Popes in The early Middle Ages, v. 1: The Popes under the Lombard Rule, St. Gregory I. (The Great) to Leo III 590-795, p. 2: 657-795, London 1914.

McCormick M., Gregory of Tours on Sixth-Century Plague and other Epidemics, "Speculum" 96/1 (2021) p. 38-96.

McKitterick R., Rome and the Invention of the Papacy. The Liber Pontificalis, Cambridge 2020 .

Maddicott J.R., Plague in Seventh-Century England, "Past and Present" 156 (1997) p. 7-54.

Noble T.X., The Republic of St. Peter, The Birth of The Papal State (680-825), Philadelphia 1991.

Potter D.S., The Roman Empire at Bay AD 180-395, London - New York 2004.

Roy J., Saint Nicholas I, London 1901.

Rubery E., Conflict or Collusion? Pope Martin (649-654/5) and the Exarch Olympius in Rome after the Lateran Synod of 649, „Studia Patristica” 52 (2012) p. 339-367.

Sessa K., Exceptionality and Invention: Silvester and the Late Antique 'Papacy' at Rome, "Studia Patristica" 46 (2010) p. 77-94.

Sheedy C.E., Deusdedit, Pope, St., in: New Catholic Encyclopedia, v. 4, New York 1967, p. 822.

Sigal P.-A., Sickness of the Pope, Middle Ages, in: The Papacy, An Encyclopedia, v. 3, ed. P. Levillain, New York - London 2002, p. 1415-1417.

Sotinel C., Vigilius, in: The Papacy, An Encyclopedia, v. 3, ed. P. Levillain, New YorkLondon 2002, p. 1616-1618.

Stathakopoulos D., Famine and Pestilence in the Late Roman and Early Byzantine Empire, New York 2004.

Stavrianeas N.G. - Toumbis Ioannou E., Constantine the Great and leprosy: fact or fiction?, "Clinics in Dermatology" 27 (2009) p. 139-141.

Ullmann W., A Short History of the Papacy in the Middle Ages, London - New York 2005.

Vogel C., Liber Pontificalis, in: Encyclopedia of Ancient Christianity, v. 2, ed. A. Di Berardino, Downers Grove 2014, p. 564.

Woods D., Olympius and the "Saracens" of Sicily, "Byzantine and Modern Greek Studies” 27 (2003) p. 262-265. 